\title{
An Integrated Approach to Assessing an Organization's Knowledge Potential
}

\author{
Jurgita Raudeliuniene $^{1}$, Marek Szarucki ${ }^{2}$
}

${ }^{1}$ Vilnius Gediminas Technical University

Sauletekio av. 11, LT-10223 Vilnius, Lithuania

E-mail.jurgita.raudeliuniene@vgtu.lt

${ }^{2}$ Cracow University of Economics

Rakowicka 27, 31-510 Krakow, Poland

E-mail.marek.szarucki@uek.krakow.pl

cross $^{\text {ref }}$ http://dx.doi.org/10.5755/j01.ee.30.1.20807

In the context of globalization and transformations, efficient knowledge potential assessment and management is a powerful way for increasing the performance of organizations. Knowledge potential is defined as a whole of organization's resources and market opportunities, and its complex assessment and efficient management create preconditions for satisfying changing customers' needs, creating value and uniqueness in the marketplace. Most researchers emphasize that the crucial components of the organization's knowledge potential should be integrated and balanced in the assessment of knowledge management since in the complexity and uncertainty of knowledge management environment it is difficult to forecast and anticipate the results the organization is trying to achieve. As a consequence of this, the approaches and methods of the assessment of the factors that influence the external and internal knowledge potential are regarded as controversial in the scientific literature and practice. Different approaches that analyse the aspects of knowledge potential assessment interpret and evaluate the organization's knowledge potential differently. In this research, these problems are analysed by examining and integrating contemporary management approaches and theories, different attitudes of researchers toward external and internal factors that influence knowledge potential, and their assessment aspects. The aim of this research is to present the peculiarities of the organization's knowledge potential assessment in the context of transformations and a theoretical framework of the influence of knowledge potential on the organization's performance. To conduct the research, the analysis of scientific literature, systematic analysis, and methods of synthesis were applied, and the results of the empirical research conducted by the authors (Raudeliuniene, 2017; Raudeliuniene et al., 2018) were integrated. The theoretical framework of the influence of knowledge potential on the organizational performance creates preconditions and research development guidelines for assessing factors impacting the performance of knowledge management and the organization itself.

Keywords: Knowledge Potential; Knowledge Management; Knowledge Management Processes; Assessment.

\section{Introduction}

Under conditions of global transformations, the crucial components of knowledge potential management have to be integrated and balanced in the assessment of knowledge management (Bivainis \& Morkvenas 2012; Chen et al., 2009; Fink, 2011; Huang et al., 2011; Hunitie, 2017; Ragab \& Arisha, 2013; Stewart, 1997), as in the complexity and uncertainty of the knowledge management environment, it is difficult to forecast and anticipate the results the company is trying to achieve. As a consequence of this, the factors, approaches, and methods of the assessment of external and internal factors that influence knowledge potential regarded as controversial in the scientific literature and practice, change as well.

An organization's knowledge potential for the aim of this research will be perceived as a whole of organization's resources (human, organizational, technological, knowledge, financial) and market opportunities which generates the capacity of organizational knowledge. Complex assessment and efficient management of knowledge potential create preconditions for satisfying changing individual customers' needs, creating mutual value, uniqueness, and leadership in the local or global market (Raudeliuniene, 2017).

For assessing the factors that influence knowledge potential, various approaches (Chen et al., 2009; Fink, 2011; Hu et al., 2015; Jang et al., 2014; Ragab \& Arisha, 2013), models, and methods (Bivainis \& Morkvenas, 2012; Fink, 2011; Jang et al., 2014) are proposed in the scientific literature. All of them have their own specific purpose and assessment limitations.

Knowledge potential assessment methods should not only evaluate the factors that influence knowledge potential, but also the interaction between these factors, as intellectual capital emerges from the interaction of human, structural, and customer capital (Stewart, 1997).

Various approaches that study knowledge potential assessment interpret and evaluate the organization's knowledge potential differently. In this research, these problems are analysed by studying and integrating contemporary management approaches and theories, different researchers' attitudes toward external and internal factors that influence knowledge potential, and their assessment methods. 
The results of the scientific research have shown that the structural approach, which is characterized by the strategic management model based on the external environment, functions, and organization's financial results are about 20 percent dependent on the market segment and about 36 percent of the organization's financial results are related to the organizational competencies and resources possessed as well as the decisions made (Hitt, Ireland, \& Hoskisson, 2007; McGahan, 1999). Thus, both the structural approach and the strategical management model, the latter of which is based on the organization's internal factors, are significant while evaluating the potential of organizational knowledge and increasing organization's value.

As a consequence of this, researchers started searching for integrated approaches, models, methods, and means with an aim to assess the already possessed knowledge potential in a more complex way (Bivainis \& Morkvenas 2012; Chen et al., 2009; Fink, 2011; Huang et al., 2011; Hunitie, 2017; Koohang et al., 2017; Ragab \& Arisha, 2013; Tubigi \& Alshawi, 2015), which is related to efficient knowledge potential management and value creation.

The aim of this research is to present the peculiarities of the organization's knowledge potential assessment in the context of transformations and a theoretical framework of the influence of knowledge potential on the performance of an organization. The theoretical framework of the influence of knowledge potential on the organizational performance creates preconditions and research development guidelines for assessing factors impacting the performance of knowledge management and the organization itself. To conduct the research, the analysis of scientific literature, systematic analysis, and methods of synthesis were applied and the results of the empirical research conducted by the authors (Raudeliuniene, 2017; Raudeliuniene et al., 2018) were integrated.

\section{The Approaches to the Organization's Knowledge Potential Assessment}

How to efficiently assess the organization's knowledge potential and shape knowledge potential management solutions as limited organization's resources in seeking uniqueness and leadership in the market exist in a dynamic and uncertain environment - such a problem is examined in knowledge management discipline and is realized in practice through the process of the knowledge management cycle that creates preconditions for creating mutual value for both the customers and the members of the organization.

In this research, knowledge management is defined as purposeful and systematic management of processes, methods, and means at the same time comprehensively utilizing the organization's knowledge potential for forming strategic goals, making and implementing efficient decisions for creating organization's value (Raudeliuniene, 2017).

When analysing the process approach of knowledge management, researchers (Agarwal \& Islam, 2014, 2015; Becerra-Fernandez, Gonzalez, \& Sabherwal, 2004; Bigliardi, Galati, \& Petroni, 2014; Costa \& Monteiro, 2016; Dalkir, 2011; Franco \& Mariano, 2007; Garcia-Fernandez, 2015; Kianto et al., 2016; Koohang et al., 2017; Lin \& Lee, 2005; Mcelroy, 1999; Meyer \& Zack, 1996; O’Dell \&
Hubert, 2011; Obeidat et al., 2016; Pinho et al., 2012; Probst et al., 2000; Ranjbarfard et al., 2014; Rollett, 2003; Rusly, Corner, \& Sun, 2012; Sun, 2010; Supyuenyong et al., 2009; Tubigi \& Alshawi, 2015; Wee \& Chua, 2013; Wiig, 1993; Yusr et al., 2017) distinguish different combinations of knowledge potential management processes.

On the basis of the conducted scientific research (Raudeliuniene, 2017; Raudeliuniene et al., 2018), it was found that researchers usually study such knowledge management processes as (1) knowledge allocation, distribution, knowledge sharing, transfer, and dissemination; (2) knowledge creation and development; (3) knowledge acquisition and (4) knowledge application, repeated knowledge application; (5) knowledge preservation, accumulation of knowledge. The analysis of the scientific literature has shown that knowledge management processes analysed by most researchers do not have clear knowledge management structure and feedback aspects, which are important for assessing the process model of knowledge management which includes the beginning of the process cycle and the completion of the cycle; due to the diversity of approaches, it is difficult to comprehensively evaluate knowledge management processes. To solve these problems, the integrated knowledge management cycle proposed by G. Probst, S. Raub and K. Romhardt (2000) was improved (Probst et al., 2000).

The improved process model of knowledge management (Raudeliuniene, 2017; Raudeliuniene et al., 2018) includes the stages of knowledge strategy formation, selection, and implementation through the knowledge management cycle. The knowledge management cycle consists of knowledge acquisition, development, preservation, sharing, and application processes. The knowledge management process model is completed with the assessment of the implementation of knowledge strategy.

In the knowledge management process model, the external and internal factors which influence knowledge potential and are regarded as controversial by researchers, are evaluated. The analysis of external and internal factors that influence knowledge potential faces a variety of approaches (Bivainis \& Morkvenas, 2012; Fink, 2011) and methods (Bivainis \& Morkvenas 2012; Chen et al., 2009; Fink, 2011; Hu et al., 2015; Jang et al., 2014; Ragab \& Arisha, 2013), and a range of factor assessment approaches (Bolisani \& Scarso, 2016; Chang, Hsu, \& Yen, 2012; Chen et al., 2011; Gharehbiglo et al., 2012; Huang et al., 2011; Hunitie, 2017; Koohang et al., 2017; Lee \& Wong, 2015; Lin, 2014; Tubigi \& Alshawi, 2015).

K. Fink (2011) analyses the cognitive science and management theory approaches. Cognitive science is related to the nature of intelligence, individual's behaviour in the process of cognition and includes philosophy, psychology, neurology, artificial intelligence, languages, culture, and cognition. The management theory approach is related to the assessment factors of the organization's intangible assets or intellectual capital, and, as a consequence of that, theories and methods of organization's knowledge asset assessment on the levels of individual (knowledge potential assessment method), organization (market capitalization, return on assets methods), structural unit, process (resultative, direct intellectual capital methods) emerged (Fink, 2011). 
Y. Hu, J. Wen and Y. Yan (2015) classify the methods that assess the value of knowledge resources into macro (the overall value of the knowledge resources in an organization is analysed) and micro (the value of separate knowledge resources is analysed) levels. Macro approach is divided into static (Skandia Navigator, Technology Broker) and dynamic (the value of knowledge; the map of the value of knowledge assets) assessment. The dynamic approach is useful when evaluating the value of knowledge resources across a period of time, but many aspects of uncertainty still exist in these models. Micro methods are divided into financial and nonfinancial aspects (Hu et al., 2015).

M. Y. Chen, M. J. Huang and Y. C. Cheng (2009) divide knowledge potential assessment methods into qualitative and quantitative. Qualitative assessment methods are a survey, expert interview, and crucial success factors. Quantitative research methods are divided into the analysis of financial indicators (return on investment and others), the analysis of non-financial indicators (community practices; individual, knowledge content, and process assessment), internal performance analysis (assessment based on performance), external performance analysis (comparative analysis, good practice), projectoriented analysis (social models; the management model of knowledge management project), and organizationoriented analysis (intellectual capital) (Chen et al., 2009).

Based on the analysis of scientific literature M. A. F. Ragab and A. Arisha (2013), they classify knowledge potential assessment methods into three groups: financial methods (Tobin's Q method; economic value added; human resources accounting; value creation intellectual coefficient), the methods of intellectual capital (Skandia Navigator method; intellectual capital index; observing intangible assets; intellectual capital rating; map of knowledge assets; intellectual capital audit) and the assessment methods of knowledge management activity (Ragab \& Arisha, 2013).

J. Jang, J. Yang and A. Hong (2014) divide knowledge potential assessment methods into the traditional and subjective ones. The traditional assessment methods are a financial analysis of knowledge assets using financial indicators. Another group of methods is related to subjective knowledge potential assessment factors. According to the researchers, the second group of methods is much more efficient as organizations have different management principles and characteristics of knowledge potential, but when these methods are applied, the problems of comparability are faced (Jang et al., 2014).

For evaluating knowledge potential, J. Bivainis and R. Morkvenas (2012) suggest the multilevel structure of knowledge potential that is composed of five-tiered hierarchy ranging from an individual, employee, organization, economic sector to the country level. Researchers developed a model for the organization's knowledge potential assessment that is person-oriented and includes all the constituents of knowledge (expressive and inexpressive knowledge, and their synergy). The model includes calculating the synergy of knowledge potential and employees' knowledge potential, and assessment of the organization's external medium (Bivainis \& Morkvenas, 2012).
K. Fink (2011) suggests the knowledge potential assessment model that integrates Heisenberg's uncertainty principles and quantum mechanics approach when knowledge employees are seen as indivisible energy units and each employee's knowledge potential is assessed through the aspects of knowledge mass, speed, and position. Knowledge mass is related to the human factor (content, network, abilities, learning environment) and is defined as a whole of human variables which impacts the expert knowledge potential and is assessed through four variables: content, network, abilities, and learning environment. The knowledge position is related to the organizational structure and industry factors (culture, customer, competitor, knowledge management system, organization's knowledge) that influence the creation of knowledge worker's potential and cannot directly depend on knowledge worker's influence. Knowledge speed is assessed through the prism of quality and time. After assessing knowledge workers' potential, estimates are obtained. They consist of five skill acquisition levels: Novice, Advanced Beginner, Competent, Proficient, and Expert. Taking into account the position of the skill acquisition level, further, the decisions related to the implementation of knowledge processes and systems are formed (Fink, 2011).

J. Jang, J. Yang and A. Hong (2014) proposed an assessment tool integrating the quantum mechanics approach: knowledge speed (the speed and quality of human capital, how fast the reaction and decision-making are), mass (the process of knowledge creation for individuals and their environmental factors), and position (how the organization cooperates with others to achieve cost-effectiveness, how many knowledge resources they have, and what support the state provides), and interaction between them (Jang et al., 2014).

The analysis of external and internal factors that influence knowledge potential faces a variety of approaches and a range of factor assessment approaches (Bivainis \& Morkvenas 2012; Bolisani \& Scarso, 2016; Chang et al., 2012; Chen et al., 2011; Gharehbiglo et al., 2012; Huang et al., 2011; Hunitie, 2017; Koohang et al., 2017; Lee \& Wong, 2015; Lin, 2014; Tubigi \& Alshawi, 2015) (Table 1).

For assessing the synergy of the organization's knowledge potential, J. Bivainis and R. Morkvenas (2012) propose an algorithm based on analytical estimations for assessing factors such as the compatibility of organizational structure, the size of the organization, the ability of the organization's staff to use information technology. To assess the influence of external relations the organization's knowledge potential is corrected by the knowledge potential coefficient of the organization's external medium. For calculating this coefficient, the knowledge economy index from the World Bank knowledge assessment methodology was adapted (Bivainis \& Morkvenas, 2012).

On the basis of the results of the study, conducted by the researchers (Bivainis \& Morkvenas, 2012), for analysing the external factors that influence knowledge potential, various external environment (at macro and micro levels) competitiveness and knowledge economy indexes applied by international institutions can be adapted. 


\section{Jurgita Raudeliuniene, Marek Szarucki. An Integrated Approach to Assessing an Organization's Knowledge Potential}

W. Chen, M. Elnaghi and T. Hatzakis (2011) studied the most significant knowledge management factors that influence information and communication technology organizations in China: organizational culture (cooperation, trust, learning), structure (centralization, formalization), and knowledge management systems. The research results showed that an organization's cultural environment was identified as the crucial constituent, as well as collaborative, trusted, and training-oriented environment that had a positive impact on organization's efficiency (Chen et al., 2011).

External and Internal Factors that Influence Knowledge Potential (Created by the Authors)

Table 1

\begin{tabular}{|c|c|c|}
\hline Author, year & Internal factors that influence knowledge potential & $\begin{array}{c}\text { External factors that influence knowledge } \\
\text { potential }\end{array}$ \\
\hline Chen et al., 2011 & $\begin{array}{l}\text { - Organizational culture } \\
\text { - Structure } \\
\text { - Knowledge management systems }\end{array}$ & P \\
\hline Huang et al., 2011 & $\begin{array}{l}\text { - Individual characteristics } \\
\text { - Information technology support } \\
\text { - Promotion of knowledge management } \\
\text { - Organization's characteristics } \\
\text { - Cultural factors } \\
\text { - Perceived utility } \\
\text { - Knowledge management practice } \\
\text { - Expected utility }\end{array}$ & $\begin{array}{l}\text { - Environmental and market segment factors: } \\
\text { sector competitiveness, trends, regulation, } \\
\text { customers' complaints, information and } \\
\text { communication technology development }\end{array}$ \\
\hline Bivainis \& Morkvenas 2012 & $\begin{array}{l}\text { - Compatibility of organizational structure } \\
\text { - The size of the organization } \\
\text { - The ability of the organization's staff to use } \\
\text { information technology }\end{array}$ & $\begin{array}{l}\text { - External environment (at macro and micro } \\
\text { levels) competitiveness and knowledge } \\
\text { economy indexes applied by international } \\
\text { institutions can be adapted }\end{array}$ \\
\hline Chang et al., 2012 & $\begin{array}{l}\text { - Target characteristics } \\
\text { - Knowledge management processes } \\
\text { - Capabilities of knowledge management systems }\end{array}$ & - \\
\hline Gharehbiglo et al., 2012 & $\begin{array}{l}\text { - Human resources } \\
\text { - Information technology } \\
\text { - Organizational culture } \\
\text { - Organizational structure } \\
\text { - Training and retraining } \\
\end{array}$ & - \\
\hline Lin, 2014 & $\begin{array}{l}\text { - Technological support } \\
\text { - Organizational environment }\end{array}$ & - Intensity of competition \\
\hline Lee \& Wong, 2015 & $\begin{array}{l}\text { - Knowledge resources } \\
\text { - Knowledge management processes } \\
\text { - Knowledge management factors } \\
\end{array}$ & - \\
\hline Tubigi \& Alshawi, 2015 & $\begin{array}{l}\text { - Financial assessment } \\
\text { - Assessment of processes } \\
\text { - Assessment of human resource development } \\
\text { - Long range planning of organization }\end{array}$ & - Customer and market assessment \\
\hline Bolisani \& Scarso, 2016 & $\begin{array}{l}\text { - Technical factors } \\
\text { - Economic factors } \\
\text { - Process factors } \\
\text { - Organizational factors } \\
\text { - Cultural factors }\end{array}$ & - \\
\hline Hunitie, 2017 & $\begin{array}{l}\text { - Human resources } \\
\text { - Perceived utility } \\
\text { - Difficulty } \\
\text { - Knowledge management-oriented technologies }\end{array}$ & - \\
\hline Koohang et al., 2017 & $\begin{array}{l}\text { - Efficiency } \\
\text { - Effectiveness } \\
\text { - Product quality } \\
\text { - Productivity } \\
\text { - Quality of work life } \\
\text { - Innovation } \\
\text { - Profitability }\end{array}$ & - \\
\hline
\end{tabular}

L. S. Huang, M. Quaddus, A. L. Rowe and C. P. Lai (2011) identified the crucial factors that influence the life insurance business in Taiwan when knowledge management principles are applied in an organization. Researchers integrated external and internal factors that influence knowledge potential (12 factor groups and 93 primary assessment criteria), such as: environmental and market segment factors (sector competitiveness, trends, regulation, customers' complaints, information and communication technology development), individual characteristics (education, position, computer skills, individual innovation, attitude toward work, personal 
qualities, loyalty to organization), information technology support (infrastructure, data security, communication, functionality, and others), promotion of knowledge management (knowledge management manual, plans, work group, top-level management support, financial resources, trainings, knowledge transmission channels, knowledge type, knowledge management assessment, and others), organization's characteristics (size, structure, strategy, and policy, learning, range of products, and others), cultural factors (knowledge-intensive culture, work group culture, trust, respect), perceived utility (quality of work, time consumption, effectiveness, professional competence, error reduction, and others), knowledge management practice (knowledge identification, preservation, application, sharing, and other), expected utility (customer service, expense reduction, adjustment to changes, reputation), and others.

The research results showed that some of the crucial factors that influence knowledge potential are technical and programme infrastructure, knowledge management manual, top-level management support, target orientation of an organization, knowledge accumulation, and attitude toward knowledge management (Huang et al., 2011).

C. M. Chang, M. H. Hsu and C. H. Yen (2012) integrated two knowledge management approaches (first, the compliance with knowledge processes and objectives; second, the compliance with the capabilities of knowledge management systems and processes determines the operation of knowledge management) with an aim to test if the target characteristics (process- and content-oriented), knowledge management processes (socialization, externalization, combination, internalization), and capabilities of knowledge management systems influence the efficiency of knowledge management (knowledge quality, satisfaction with knowledge, creativity). The research results confirmed that compliance with target characteristics, knowledge management processes, and knowledge management systems influence the efficiency of knowledge management (Chang et al., 2012).

H. Gharehbiglo, B. Shadidizajib, S. Yazdanic and R. Khandehzamin (2012) evaluated the most significant factors that influence knowledge management in public administration: information technology, organizational culture, human resources, organizational structure, training, and retraining. The research results confirmed the hypothesis that there is a positive link between information technology, organizational culture, human resources, organizational structure, education, and training (Gharehbiglo et al., 2012).

On the basis of the knowledge management approach, innovation diffusion theory, and the structure based on technology-organization-environment H. F. Lin (2014) analysed the influence of technological support (the support and effectiveness of information technology), organizational environment (top-level management support, sharing culture, reward system), and factors of the external environment (intensity of competition) on small and medium-sized business organizations at the stages of knowledge management adoption and implementation. Study results confirmed that in small and medium-sized business organizations the implementation of knowledge management principles depends on technological, organizational, and external environment factors. Information technology support and effectiveness, toplevel management support, and reward system were identified as crucial factors at the stage of adaptation of knowledge management principles. Information technology support and effectiveness, top-level management support, knowledge sharing culture, and intensity of competition are significant factors at the stage of implementation. Information technology support has the most influence on the stage of knowledge management adoption, while knowledge sharing culture has the most influence on the stage of knowledge management implementation (Lin, 2014).

C. S. Lee and K. Y. Wong (2015) analysed the model of knowledge management assessment for small and medium-sized organizations integrating three factor groups: knowledge resources (human capital, knowledge capital, intellectual property), knowledge management processes (knowledge acquisition, creation, application, preservation, sharing), knowledge management factors (organizational infrastructure, strategy, resources, human resource management) (Lee \& Wong, 2015).

M. Tubigi and S. Alshawi (2015) analysed the influence of knowledge management processes on the organization's performance by integrating five assessment dimensions: (1) financial assessment (income, profit margin, return on investment); (2) customer and market assessment (related to the relationships between the organization's customers; customer-oriented organizations analyse their customers' needs and propose innovative solutions to satisfy these needs, so they are able to achieve high customer retention rates); (3) process assessment (reflects constant efficiency of process improvement and its extent all throughout the organization); (4) human resource development assessment (related to the stakeholders' role in achieving organizational targets, the quality of employees' skills, orientation to technology leadership, and human resource development); (5) longrange planning of organization (related to strategic planning competencies, important partnerships and agreements, readiness to act efficiently in business environment and investment into new markets and technologies) (Tubigi \& Alshawi, 2015).

E. Bolisani and E. Scarso (2016) assessed the factors that influence knowledge management in small organizations by applying wiki tool. During the study, five factor groups were identified: technical factors (integrated technical infrastructure, level of openness, security, and others), economic factors (targets and benefit, reward system, motivation, and others), process factors (technical support, functionality, content quality, and others), organizational factors (training, support from management, staff experience in information technology, and others). The research results showed that social and organizational factors are more important than technical aspects (Bolisani \& Scarso, 2016).

M. Hunitie (2017) conducted the application of knowledge management initiatives in Jordanian public organizations and divided the assessment of operating factors into such groups: perceived utility (work and service quality, compliance with work requirements, reduction of duplication work), difficulty (simplicity, 
availability, user-friendly environment), knowledge management-oriented technologies (infrastructure, understanding of technology), and human resources (employee integration). The research results showed that all the factor groups influence the application of knowledge management initiatives, while factors related to human resources are the most significant factors in knowledge management adoption (Hunitie, 2017).

A. Koohang, J. Paliszkiewicz and J. Goluchowski (2017) studied the influence of leadership on trust, knowledge management processes, and the performance of the organization. For evaluating it, such criteria as effectiveness (the ability to achieve the desired result); efficiency (the ability to perform a job or task with minimum time and effort expenses); product quality (the excellence and the qualitative product parameters that create preconditions for manufacturing the product without damage or defects are assessed; productivity (ability to creatively create, improve, and produce products or services); the quality of work life (the opportunity to improve the personal lives of employees through their work environment and experience); innovation (the process of transforming an idea into a product or service that creates value); profitability of operations (Koohang et al., 2017).

Summarizing the research results, it can be stated that the researchers are more oriented to the internal factors that influence knowledge potential than to the external ones. In Authors' opinion, it is very important to take into account external factors influencing knowledge potential.

By analysing the internal factors that influence an organization's knowledge potential, it was identified that the researchers study such crucial elements that could be classified into five groups as (Table 2):

- organizational factors (the size of the organization, organizational structure, culture, perspective planning, and others);

- $\quad$ human factors (benefit, ability to use information technology, training, incentives, and others);

- technological factors (technology support, knowledge management systems, and others);

- knowledge resources (knowledge management processes, practice, and others);

- financial factors (efficiency, productivity, the profitability of operations, and others).

The external factors that influence knowledge potential include the external environment (at macro and micro levels) competitiveness and knowledge economy indexes used by international institutions, customer and market dimensions.

To achieve the most diverse assessment of the external and internal knowledge potential management factors, it is suggested to apply the system of balanced scorecard, compiled according to the target groups and each target group includes the criteria and means for achieving targets (Kaplan \& Norton, 1996, 2004, 2006). In the model of balanced scorecard, the organization's main objective is to create and achieve financial targets that depend on organization's position in the market and ability to meet customers' needs, which is related to the efficiency of the organization's internal processes that function properly when employees are motivated and competent.

Table 2

Assessment of the Groups of Internal Factors that Influence Knowledge Potential (Created by the Authors)

\begin{tabular}{|c|c|c|c|c|c|}
\hline Author, year & $\begin{array}{c}\text { Organization } \\
\text { al factors }\end{array}$ & $\begin{array}{l}\text { Human } \\
\text { factors }\end{array}$ & $\begin{array}{c}\begin{array}{c}\text { Technological } \\
\text { factors }\end{array} \\
\end{array}$ & $\begin{array}{c}\text { Knowledge } \\
\text { resources }\end{array}$ & $\begin{array}{c}\text { Financial } \\
\text { factors }\end{array}$ \\
\hline Chen et al., 2011 & + & & + & + & \\
\hline Huang et al., 2011 & + & + & + & & \\
\hline Bivainis \& Morkvenas 2012 & + & + & & & \\
\hline Chang et al., 2012 & + & & & + & \\
\hline Gharehbiglo et al., 2012 & + & + & + & & \\
\hline Lin, 2014 & + & & + & & \\
\hline Lee \& Wong, 2015 & & + & & + & \\
\hline Tubigi \& Alshawi, 2015 & + & + & & + & + \\
\hline Bolisani \& Scarso, 2016 & + & & + & + & + \\
\hline Hunitie, 2017 & + & + & + & & \\
\hline Koohang et al., 2017 & + & + & + & + & + \\
\hline
\end{tabular}

The complexity of the assessment of the external and internal factors that influence knowledge potential, aspiration for more objective and better quality assessment results create preconditions for searching for the integrated and structured assessment approaches and methods. The application of these approaches and methods creates opportunities for evaluating the study object and forming proposals for the elimination of problematic areas. This kind of problems can be solved by applying multiple criteria assessment methods (Ginevicius, 2011; Zavadskas \& Podvezko, 2016).

Using the multiple criteria assessment methods enables to appropriatelyevaluate any complex phenomenon expressed by most indicators. These assessment methods integrate the combinations of the qualitative (expert assessment, a survey, an interview) and quantitative (methods of mathematical analysis) approaches - expert knowledge and the application of mathematical analysis 
methods. When the complex multiple criteria assessment method is applied, preconditions for conducting the comparative analysis of the alternatives and selecting such alternatives that have the highest integrated criterion estimate are created.

The selection of the multiple criteria assessment methods creates preconditions for assessing the external and internal factors in an objective and flexible way, comparing them with each other, and forming solutions to eliminate the problematic areas.

\section{Organization's Internal Factors and the External Environment Assessment Perspective}

For assessing the organization's knowledge potential, it is suggested to integrate the external (macro and micro levels) approach and the resource perspective of the organization which include organizational, human, technological, knowledge, and financial factors. The integration of these approaches creates preconditions for the complex assessment and management of the organization's knowledge potential through the knowledge management cycle: knowledge acquisition, knowledge development, preservation, sharing, and knowledge application (Raudeliuniene, 2017; Raudeliuniene et al., 2018). The proposed integrated approach for the organization's knowledge potential assessment is presented in Table 3 and discussed below.

When assessing and managing organization's human resources, it is suggested to follow such a logical causal sequence, whereby only motivated members of an organization will be interested in raising their personal, professional, social, methodical, intercultural, or management competencies which would help to ensure the efficient implementation of knowledge management processes, creation of innovative products (services), and the presentation to the customers satisfying their changing needs and creating mutual value, which creates preconditions for creating and maintaining the organization's uniqueness.

When assessing and managing the organizational factors, it is recommended to take into account the organization's target orientation, the motivational system applied by the organization, organization's top management support for implementing knowledge management practice, knowledge-intensive culture (trust, respect, cooperation, learning environment).

While assessing and managing the technological factors, it is worth to consider organization's members' need for information and communication technology, organization's infrastructure, and the efficiency of their unit that ensures the facility and efficiency of the knowledge management process.

Knowledge resources are one of the crucial knowledge management components, thus when assessing and managing these resources, it is important to consider knowledge value, availability, and their application for ensuring knowledge processes and creation of innovative products (services).

Financial resources are related to the return on human, organizational factors, technological, and knowledge resources, and the aspects of efficiency assessment and mnagement.
When assessing and managing the process of knowledge management cycle - knowledge acquisition, it should be stressed that the required competencies (knowledge abilities, skills) in the context of external and internal organizational interactions are acquired in this process in order to eliminate knowledge gaps for implementing knowledge acquisition strategy. On the basis of the conducted empirical research, it is suggested to assess knowledge acquisition process and internal integrated assessment criteria through human (motivation to obtain knowledge, competence to obtain knowledge, orientation to creating uniqueness), organizational (work environment when obtaining knowledge, infrastructure for obtaining knowledge), technological (the need for information and communication technology when obtaining knowledge, efficiency of information and communication technology applied when obtaining knowledge), knowledge (knowledge acquisition resources, value, duration, place, and level of knowledge application), and financial (preservation of human resources and infrastructure, the price and return on knowledge acquisition) resources.

In the process of knowledge development, competencies, which are not inside and outside the organization, but are crucial for knowledge strategy, are created. When assessing and managing factors that influence the process of knowledge development, it is suggested to consider human (motivation, competence, orientation to creating uniqueness, and preservation), organizational (creative climate, infrastructure for knowledge development), technological (the need for technology, infrastructure, and the efficiency of technologies applied for knowledge development), knowledge (knowledge needs, the value of the innovative projects and opportunities for their realization), and financial (human resources and infrastructure preservation, and return on innovative projects) resources.

In the process of knowledge preservation, the necessary knowledge is selected. It is stored and renewed by applying various methods and means in order to implement the knowledge strategy. When analysing and managing factors that influence knowledge preservation, it is suggested to take into account human (organization's members' motivation to preserve knowledge, competence, orientation to uniqueness), organizational (work environment in the process of knowledge preservation, infrastructure for knowledge preservation), technological (the need for information and communication technology, efficiency of the technologies applied), knowledge (value, availability, and applicability), and financial (human resources, infrastructure maintenance, and return on knowledge preserved) resources.

The process of knowledge sharing includes trust-based cooperation, during which knowledge is shared and is available for implementing the knowledge. When assessing and managing the process of knowledge sharing, it is suggested to take into account human (motivation, competence, orientation to creating and preserving uniqueness), organizational (knowledge sharing culture, infrastructure for knowledge sharing), technological (need for technology and efficiency of technologies applied), knowledge (knowledge needs, availability, opportunities 


\section{Jurgita Raudeliuniene, Marek Szarucki. An Integrated Approach to Assessing an Organization 's Knowledge Potential}

for development, and knowledge value), and financial (maintenance of human resources and infrastructure, return on encouraging knowledge sharing) resources.

In the process of knowledge application, knowledge is transformed into particular performance results and is applied for solving problems, improving the process, and implementing the knowledge strategy. For assessing and managing the process of knowledge application, human (motivation, competence, orientation to creating and preserving uniqueness), organizational (work environment when applying knowledge, infrastructure for applying knowledge), technological (the need for technology, efficiency of technologies), knowledge (knowledge value, availability, presentation form, applicability), and financial (maintenance of human resources and infrastructure, return on applicability) resource factors are suggested.

Integrated Approach of the Organization's Knowledge Potential Assessment (Created by the Authors)

\begin{tabular}{|c|c|c|c|c|c|}
\hline \multirow[b]{2}{*}{ Process } & \multicolumn{5}{|c|}{$\begin{array}{l}\text { Macro environment (social, cultural, technological, economic, political, legal) } \\
\text { nvironment (industry-related human, technological, knowledge, and financial factors) }\end{array}$} \\
\hline & Human & Organizational & Technological & Knowledge & Financial \\
\hline $\begin{array}{l}\text { Knowledge } \\
\text { acquisition }\end{array}$ & $\begin{array}{l}\text { - Motivation for } \\
\text { knowledge } \\
\text { acquisition } \\
\text { - Competence for } \\
\text { knowledge } \\
\text { acquisition } \\
\text { - Orientation to } \\
\text { creating } \\
\text { uniqueness }\end{array}$ & $\begin{array}{l}\text { - Work } \\
\text { environment for } \\
\text { knowledge } \\
\text { acquisition } \\
\text { - Infrastructure for } \\
\text { knowledge } \\
\text { acquisition }\end{array}$ & $\begin{array}{l}\text { - Need for information } \\
\text { and communication } \\
\text { technology in the } \\
\text { process of knowledge } \\
\text { acquisition } \\
\text { - Efficiency of } \\
\text { technologies applied } \\
\text { in the process of } \\
\text { knowledge acquisition }\end{array}$ & $\begin{array}{c}\text { - Sources of knowledge } \\
\text { acquisition } \\
\text { - Value of knowledge } \\
\text { content } \\
\text { - Duration of knowledge } \\
\text { acquisition } \\
\text { - Place of knowledge } \\
\text { acquisition } \\
\text { - Level of knowledge } \\
\text { applicability } \\
\end{array}$ & $\begin{array}{c}\text { - Price of knowledge } \\
\text { acquisition } \\
\text { - Maintenance of } \\
\text { human resources } \\
\text { - Maintenance of } \\
\text { infrastructure } \\
\text { - Return on knowledge } \\
\text { acquisition }\end{array}$ \\
\hline $\begin{array}{l}\text { Knowledge } \\
\text { development }\end{array}$ & $\begin{array}{l}\text { - Motivation for } \\
\text { knowledge } \\
\text { development } \\
\text { - Competence for } \\
\text { knowledge } \\
\text { development } \\
\text { - Orientation to } \\
\text { creating } \\
\text { uniqueness }\end{array}$ & $\begin{array}{c}\text { - Creative climate } \\
\text { - Infrastructure for } \\
\text { knowledge } \\
\text { development }\end{array}$ & $\begin{array}{l}\text { - Need for information } \\
\text { and communication } \\
\text { technology in the } \\
\text { process of knowledge } \\
\text { development } \\
\text { - Efficiency of } \\
\text { technologies applied } \\
\text { in the process of } \\
\text { knowledge } \\
\text { development }\end{array}$ & $\begin{array}{c}\text { - Knowledge needs } \\
\text { - Value of innovative } \\
\text { projects } \\
\text { - Possibilities for } \\
\text { implementing } \\
\text { innovative projects }\end{array}$ & $\begin{array}{c}\text { - Maintenance of } \\
\text { human resources } \\
\text { - Maintenance of } \\
\text { infrastructure } \\
\text { - Return on innovative } \\
\text { projects }\end{array}$ \\
\hline $\begin{array}{l}\text { Knowledge } \\
\text { preservation }\end{array}$ & $\begin{array}{l}\text { - Motivation for } \\
\text { knowledge } \\
\text { preservation } \\
\text { - Competence for } \\
\text { knowledge } \\
\text { preservation } \\
\text { - Orientation to } \\
\text { creating } \\
\text { uniqueness }\end{array}$ & $\begin{array}{c}\text { - Work } \\
\text { environment for } \\
\text { knowledge } \\
\text { preservation } \\
\text { - Infrastructure for } \\
\text { knowledge } \\
\text { preservation }\end{array}$ & $\begin{array}{l}\text { - Need for information } \\
\text { and communication } \\
\text { technology in the } \\
\text { process of knowledge } \\
\text { preservation } \\
\text { - Efficiency of } \\
\text { technologies applied } \\
\text { in the process of } \\
\text { knowledge } \\
\text { preservation }\end{array}$ & $\begin{array}{l}\text { - Knowledge value } \\
\text { - Knowledge availability } \\
\text { - Level of applicability } \\
\text { of knowledge } \\
\text { preserved }\end{array}$ & $\begin{array}{c}\text { - Maintenance of } \\
\text { human resources } \\
\text { - Maintenance of } \\
\text { infrastructure } \\
\text { - Return on knowledge } \\
\text { preserved }\end{array}$ \\
\hline $\begin{array}{l}\text { Knowledge } \\
\text { sharing }\end{array}$ & $\begin{array}{l}\text { - Motivation for } \\
\text { knowledge } \\
\text { sharing } \\
\text { - Competence for } \\
\text { knowledge } \\
\text { sharing } \\
\text { - Orientation to } \\
\text { creating } \\
\text { uniqueness } \\
\end{array}$ & $\begin{array}{l}\text { - Culture in the } \\
\text { process of } \\
\text { knowledge } \\
\text { sharing } \\
\text { - Infrastructure } \\
\text { for knowledge } \\
\text { sharing }\end{array}$ & $\begin{array}{c}\text { - Need for information } \\
\text { and communication } \\
\text { technologies in the } \\
\text { process of knowledge } \\
\text { sharing } \\
\text { - Efficiency of } \\
\text { technologies applied } \\
\text { in the process of } \\
\text { knowledge sharing }\end{array}$ & $\begin{array}{c}\text { - Organization's } \\
\text { members' need for } \\
\text { knowledge } \\
\text { - Knowledge availability } \\
\text { - Opportunities for } \\
\text { knowledge } \\
\text { development } \\
\text { - Knowledge value }\end{array}$ & $\begin{array}{l}\text { - Maintenance of } \\
\text { human resources } \\
\text { - Maintenance of } \\
\text { infrastructure } \\
\text { - Return on } \\
\text { encouraging } \\
\text { knowledge sharing }\end{array}$ \\
\hline $\begin{array}{l}\text { Knowledge } \\
\text { application }\end{array}$ & $\begin{array}{c}\text { - Motivation to } \\
\text { apply } \\
\text { knowledge } \\
\text { - Competence to } \\
\text { apply } \\
\text { knowledge } \\
\text { - Orientation to } \\
\text { creating } \\
\text { uniqueness } \\
\end{array}$ & $\begin{array}{c}\text { - Work } \\
\text { environment for } \\
\text { knowledge } \\
\text { application } \\
\text { - Infrastructure for } \\
\text { knowledge } \\
\text { application }\end{array}$ & $\begin{array}{l}\text { - Need for information } \\
\text { and communication } \\
\text { technologies in the } \\
\text { process of knowledge } \\
\text { application } \\
\text { - Efficiency of } \\
\text { technologies applied } \\
\text { in the process of } \\
\text { knowledge application }\end{array}$ & $\begin{array}{c}\text { - Knowledge value } \\
\text { - Knowledge availability } \\
\text { - Form of knowledge } \\
\text { presentation } \\
\text { - Level of knowledge } \\
\text { applicability }\end{array}$ & $\begin{array}{c}\text { - Maintenance of } \\
\text { human resources } \\
\text { - Maintenance of } \\
\text { infrastructure } \\
\text { - Return on knowledge } \\
\text { applicability }\end{array}$ \\
\hline
\end{tabular}


External factors that influence knowledge potential at macro (social, cultural, technological, economic, political, legal) and micro (industry-related human, technological, knowledge, and financial factors) levels
Internal factors that influence t
Organization's knowledge potential assessment and management through knowledge management processes:

Knowledge acquisition Knowledge development Knowledge preservation Knowledge sharing Knowledge application
Organization's knowledge potential management effect on organizational performance:

- Motivated and competent staff

- Satisfied customers' needs

- Financial targets achieved

- Mutual value and uniqueness of the organization created

knowledge potential (human,

organizational, technological,

knowledge, and financial factors)

Figure 1. A Theoretical Framework of the Influence of Knowledge Potential on the Organizational Performance (Created by the Authors)

In the perspective of the external environmental assessment of the organization, it is suggested to perform an evaluation at the macro (social, cultural, technological, economic, political, and legal) and micro (industry-related human, organizational, technological, knowledge, and financial factors) levels.

The process of analysing human, technological, knowledge, and financial resources that are outside an organization at the micro level (they belong to the industry-related subjects) requires taking into account the value of these resources, possibilities to acquire, attract, and apply them for implementing knowledge strategy.

When assessing human resources, it is suggested to take into account the motivation of external individuals, competencies they possess, and uniqueness creation. While analysing the possibilities to attract technological resources, it is recommended to take into account innovative possibilities that are enabled by information and communication technology provided in the external environment, their applicability and efficiency in the organization's knowledge potential management. In the process of knowledge resources acquisition, it is important to consider the value of the planned knowledge acquisition and the aspects of availability and applicability. In the perspective of financial resources, it is important to assess the return and efficiency of the resources acquired in order to achieve efficient knowledge potential management.

After summarizing the aspects of the organization's knowledge potential assessment and management, a theoretical framework of the influence of knowledge potential on the organizational performance was proposed (Figure 1). This theoretical framework presents research development guidelines and consists of the external factors that influence knowledge potential (at macro and micro levels) and the internal factors that influence knowledge potential (human, organizational, technological, knowledge resources, financial factors) which influence the efficiency of knowledge management processes (knowledge acquisition, knowledge development, knowledge preservation, knowledge sharing, knowledge application), and organizational performance.

In this research, the organizational performance is perceived as the maximum result achieved at the lowest cost and effort according to such a logical sequence (Fig. 1): only motivated and competent staff of the organization will be capable of satisfying customers' expectations, which will create preconditions for achieving financial targets, creating organization's mutual value and uniqueness in the local and global market.

\section{Conclusions}

Considering the current trends in changing global environment, an efficient knowledge potential assessment and management is a powerful way for increasing the organizational performance. The complex assessment and efficient management of knowledge potential creates preconditions for satisfying changing individual customers' needs, creating mutual value, uniqueness, and leadership in the market.

On the basis of the conducted empirical study (Raudeliuniene, 2017; Raudeliuniene et al., 2018), it is suggested to assess knowledge management processes (knowledge acquisition, development, preservation, sharing, application) by integrating external (at macro and micro levels) approach and the organization's resource perspective which include human, organizational, technological, knowledge, and financial resources. The integration of these approaches creates preconditions for complex assessment and efficient management of knowledge potential through the knowledge management cycle.

After analysing the crucial external and internal factors that influence knowledge potential in the scientific literature, a theoretical framework of the influence of knowledge potential on organizational performance was proposed. This theoretical framework presents research development 
Jurgita Raudeliuniene, Marek Szarucki. An Integrated Approach to Assessing an Organization's Knowledge Potential

guidelines and includes the external (macro and micro perspectives) and internal factors that influence knowledge potential and their influence on the efficiency of knowledge management processes and organizational performance.

The internal factors that influence knowledge potential integrate human resources (organization's members' motivation, competence, orientation to creating uniqueness), organizational factors (work environment, infrastructure), technological aspects (the need for information and communication technology, efficiency of information and communication technology applied), knowledge resources (knowledge needs, value, availability, applicability, and others), and financial (maintenance of human resources, infrastructure, and others) resources.

\section{Acknowledgement}

This work was supported by the National Science Centre Poland [grant number 2014/13/B/HS4/03452].

\section{References}

Agarwal, N. K., \& Islam, M. A. (2014). Knowledge management implementation in a library. VINE, 44(3), $322-344$. https://doi.org/10.1108/VINE-01-2014-0002

Agarwal, N. K., \& Islam, M. A. (2015). Knowledge retention and transfer: how libraries manage employees leaving and joining. VINE, 45(2), 150-171. https://doi.org/10.1108/VINE-06-2014-0042

Becerra-Fernandez, I., Gonzalez, A., \& Sabherwal, R. (2004). Knowledge management: challenges, solutions, and technologies. N.J.: Pearson Prentice Hall.

Bigliardi, B., Galati, F., \& Petroni, A. (2014). How to effectively manage knowledge in the construction industry. Measuring Business Excellence, 18(3), 57-72.

Bivainis, J., \& Morkvenas, R. (2010). Quantitative model of organization's knowledge potential assessment. In The 6th International Scientific Conference "Business and Management 2010", Selected papers (pp. 586-594). Vilnius, Lithuania. https://doi.org/10.3846/bm.2010.078

Bivainis, J., \& Morkvenas, R. (2012). Integrated assessment of organization's knowledge potential. Journal of Business Economics and Management, 13(1), 81-94. https://doi.org/10.3846/16111699.2011.620152

Bolisani, E., \& Scarso, E. (2016). Factors affecting the use of wiki to manage knowledge in a small company. Journal of Knowledge Management, 20(3), 423-443. https://doi.org/10.1108/JKM-05-2015-0205

Chang, C. M., Hsu, M. H., \& Yen, C. H. (2012). Factors affecting knowledge management success: the fit perspective. Journal of Knowledge Management, 16(6), 847-861. https://doi.org/10.1108/13673271211276155

Chen, M. Y., Huang, M. J., \& Cheng, Y. C. (2009). Measuring knowledge management performance using a competitive perspective: An empirical study. Expert Systems with Applications, 36(4), 8449-8459. https://doi.org/10.10 16/j.eswa.2008.10.067

Chen, W., Elnaghi, M., \& Hatzakis, T. (2011). Investigating knowledge management factors affecting Chinese ICT firms performance: An integrated KM framework. Information Systems Management, 28(1), 19-29. https://doi.org/10.10 80/10580530.2011.536107

Costa, V., \& Monteiro, S. (2016). Key knowledge management processes for innovation: a systematic literature review. VINE Journal of Information and Knowledge Management Systems, 46(3), 386-410. https://doi.org/10.11 08/VJIKMS-02-2015-0017

Dalkir, K. (2011). Knowledge Management in Theory and Practice. (MIT Press, Ed.). Cambridge.

Fink, K. (2011). Process model for knowledge potential measurement in SMEs. In Strategies for Knowledge Management Success: Exploring Organizational Efficacy (pp. 91-105). New York: Information Science Reference. https://doi.org/10.4018/978-1-60566-709-6.ch006

Franco, M., \& Mariano, S. (2007). Information technology repositories and knowledge management processes: A qualitative analysis. VINE, 37(4), 440-451. https://doi.org/10.1108/03055720710838515

Gharehbiglo, H., Shadidizaji, B., Yazdani, S., \& Khandehzamin, R. (2012). The survey of affecting factors on knowledge management (Case study: Municipality of the city of Rasht in Iran). Procedia -Social and Behavioral Sciences, 62, 1155-1163. https://doi.org/doi: 10.1016/j.sbspro.2012.09.198 
Ginevicius, R. (2011). A new determining method for the criteria weights in multicriteria evaluation. International Journal of Information Technology \& Decision Making, 10(06), 1067-1095. https://doi.org/10.1142/S021 9622011004713

Hitt, M. A., Ireland, R. D., \& Hoskisson, R. E. (2007). Strategic Management: Competitiveness and Globalization (Concepts and Cases) (7th Edition). Thomson South-Western.

$\mathrm{Hu}$, Y., Wen, J., \& Yan, Y. (2015). Measuring the performance of knowledge resources using a value perspective: integrating BSC and ANP. Journal of Knowledge Management, 19(6), 1250-1272. https://doi.org/10.1108/JKM-102014-0431

Huang, L. S., Quaddus, M., Rowe, A. L., \& Lai, C. P. (2011). An investigation into the factors affecting knowledge management adoption and practice in the life insurance business. Knowledge Management Research \& Practice, 9 , 58-72. https://doi.org/10.1057/kmrp.2011.2

Hunitie, M. (2017). Factors affecting knowledge management adoption in public organizations. International Journal of Advanced and Applied Sciences, 4(1), 40-46. https://doi.org/10.21833/ijaas.2017.01.006

Jang, J., Yang, J., \& Hong, A. (2014). Measurement of knowledge potential in the ICT service industry: a quantum mechanics view. In Proceedings of the 11th International Conference on Intellectual Capital, Knowledge Management and Organisational Learning (pp. 248-258).

Kaplan, R. S., \& Norton, D. P. (1996). The balanced scorecard: translating strategy into action. Boston: Harvard Business School Press.

Kaplan, R. S., \& Norton, D. P. (2004). Strategy maps: converting intangible assets into tangible outcomes. Harvard Business School Press.

Kaplan, R. S., \& Norton, D. P. (2006). Alignment: using the balanced scorecard to create corporate synergies. Harvard Business School Press.

Kianto, A., Vanhala, M., \& Heilmann, P. (2016). The impact of knowledge management on job satisfaction. Journal of Knowledge Management, 20(4), 621-636. https://doi.org/10.1108/JKM-10-2015-0398

Koohang, A., Paliszkiewicz, J., \& Goluchowski, J. (2017). The impact of leadership on trust, knowledge management, and organizational performance: A research model. Industrial Management \& Data Systems, 117(3), 521-537. https://doi.org/10.1108/IMDS-02-2016-0072

Lee, C. S., \& Wong, K. Y. (2015). Development and validation of knowledge management performance measurement constructs for small and medium enterprises. Journal of Knowledge Management, 19(4), 711-734. https://doi.org/10.1108/JKM-10-2014-0398

Lin, H. F. (2014). Contextual factors affecting knowledge management diffusion in SMEs. Industrial Management \& Data Systems, 114(9), 1415-1437. https://doi.org/10.1108/IMDS-08-2014-0232

Lin, H. F., \& Lee, G. G. (2005). Impact of organizational learning and knowledge management factors on e-business adoption. Management Decision, 43(2), 171-188. https://doi.org/10.1108/00251740510581902

Mcelroy, M. W. (1999). The Knowledge Life Cycle An Executable Model For The Enterprise. Miami, FL.

McGahan, A. M. (1999). Competition, strategy, and business performance. California Management Review, 41(3), 74101. https://doi.org/10.2307/41165998

Meyer, M. H., \& Zack, M. H. (1996). The design and development of information products. Sloan Management Review, 37(3), 43-59.

O'Dell, C. S., \& Hubert, C. (2011). The new edge in knowledge: how knowledge management is changing the way we do business. New Jersey: Wiley.

Obeidat, B. Y., Al-Suradi, M. M., Masa'deh, R., \& Tarhini, A. (2016). The impact of knowledge management on innovation: An empirical study on Jordanian consultancy firms. Management Research Review , 39(10), 1214-1238. https://doi.org/10.1108/MRR-09-2015-0214

Pinho, I., Rego, A., \& Pina e Cunha, M. (2012). Improving knowledge management processes: a hybrid positive approach. Journal of Knowledge Management, 16(2), 215-242. https://doi.org/10.1108/13673271211218834

Probst, G., Raub, S., \& Romhardt, K. (2000). Managing knowledge: building blocks for success. John Wiley \& Sons.

Ragab, M. A. F., \& Arisha, A. (2013). Knowledge management and measurement: a critical review. Journal of Knowledge Management, 17(6), 873-901. https://doi.org/10.1108/JKM-12-2012-0381

Ranjbarfard, M., Aghdasi, M., Lopez-Saez, P., \& Lopez, J. E. N. (2014). The barriers of knowledge generation, storage, distribution and application that impede learning in gas and petroleum companies. Journal of Knowledge Management, 18(3), 494-522. https://doi.org/10.1108/JKM-08-2013-0324 
Raudeliuniene, J. (2017). Organizacijos ziniu potencialo vertinimo aktualijos [Topicalities of the organization's knowledge potential assessment]. Vilnius: Technika. https://doi.org/https://doi.org/10.20334/2017-065-M

Raudeliuniene, J., Davidaviciene, V., \& Jakubavicius, A. (2018). Knowledge management process model. Entrepreneurship and Sustainability Issues, 5(3), 542-554. https://doi.org/https://doi.org/10.9770/jesi.2018.5.3(10)

Rollett, H. (2003). Knowledge management: processes and technologies. Boston: Kluwer Academic Publishers. https://doi.org/10.1007/978-1-4615-0345-3

Rusly, F. H., Corner, J. L., \& Sun, P. (2012). Positioning change readiness in knowledge management research. Journal of Knowledge Management, 16(2), 329-355. https://doi.org/10.1108/13673271211218906

Stewart, T. A. (1997). Intellectual Capital: The New Wealth of Organizations (1st ed.). New York: Doubleday.

Sun, P. (2010). Five critical knowledge management organizational themes. Journal of Knowledge Management, 14(4), 507-523. https://doi.org/10.1108/13673271011059491

Supyuenyong, V., Islam, N., \& Kulkarni, U. (2009). Influence of SME characteristics on knowledge management processes: The case study of enterprise resource planning service providers. Journal of Enterprise Information Management, 22(1/2), 63-80. https://doi.org/10.1108/17410390910922831

Tubigi, M., \& Alshawi, S. (2015). The impact of knowledge management processes on organisational performance: The case of the airline industry. Journal of Enterprise Information Management, 28(2), 167-185. https://doi.org/10.11 08/JEIM-01-2014-0003

Wee, J. C. N., \& Chua, A. Y. K. (2013). The peculiarities of knowledge management processes in SMEs: the case of Singapore. Journal of Knowledge Management, 17(6), 958-972. https://doi.org/10.1108/JKM-04-2013-0163

Wiig, K. M. (1993). Knowledge Management Foundations: Thinking about Thinking - how People and Organizations Represent, Create, and Use Knowledge. Arlington, TX: Schema Press.

Yusr, M. M., Mokhtar, S. S. M., Othman, A. R., \& Sulaiman, Y. (2017). Does interaction between TQM practices and knowledge management processes enhance the innovation performance? International Journal of Quality \& Reliability Management, 34(7), 955-974. https://doi.org/10.1108/IJQRM-09-2014-0138

Zavadskas, E. K., \& Podvezko, V. (2016). Integrated determination of objective criteria weights in MCDM. International Journal of Information Technology \& Decision Making, 15(2), 267-283. https://doi.org/10.1142/S021 9622016500036

The article has been reviewed.

Received in May, 2018; accepted in January, 2019. 